\title{
Proteomic approach to understanding the maternal effect in the flesh fly, Sarcophaga bullata (Diptera: Sarcophagidae)
}

\author{
Aiging LI, Liangliang WANG, Min LiANG, Qiugen ZHOU, Guobao WANG and Fanfan HOU*
}

Key Lab for Organ Failure Research, Ministry of Education of China, Nanfang Hospital, Southern Medical University, 1838 North Guangzhou Avenue, Guangzhou, 510515, P.R. China

Key words. Diptera, Sarcophagidae, Sarcophaga bullata, maternal effect, short-day history, proteomic, actin-binding, diapause

\begin{abstract}
Progeny of the flesh fly Sarcophaga bullata exposed to short day length show a maternal effect that prevents the expression of pupal diapause. Although ecological aspects of this effect are well studied, not enough is known about the molecular mechanisms underlying this maternal effect. In this study, two-dimensional electrophoresis was performed to detect differences of the abundance of certain proteins in the ovaries of this fly kept under long day and short day conditions for 2 days after eclosion. Eleven proteins that were abundant and showed significant changes were selected for mass spectrometric identification. Ovary proteins that increased in abundance under short-day conditions were similar to twinstar CG4254-PA, muscle protein 20-like protein, GA13413-PA, gene analogous to small peritrophins (Gasp CG10287-PA) and Ribosomal protein LP1 CG4087-PA. Ovary proteins that decreased in abundance under short-day conditions were similar to the ATP synthase beta subunit, fk506-binding protein and storage protein-binding protein. The 2-D proteome maps included 2 additional unknown proteins that were more abundant and 1 that was less abundant in the ovaries of 2-day old short-day females. Twinstar CG4254-PA, muscle protein 20-like protein and GA13413-PA harbour an actin-binding domain. That the 3 actin-binding proteins increase in abundance suggests that it is likely that an alteration in the actin cytoskeleton is involved in this maternal effect in the flesh fly.
\end{abstract}

\section{INTRODUCTION}

Previous research indicates that female flesh flies, Sarcophaga bullata, can prevent their progeny from entering pupal diapause (Henrich \& Denlinger, 1982; Rockey et al., 1989). In this fly, the mother's photoperiodic history determines whether the progeny enter diapause in response to short day-length. Diapause can not be induced in the progeny of mothers who have undergone pupal diapause, even if the progeny are reared at a short day-length, i.e., diapause-inducing conditions. Diapause can be induced only in the progeny of mothers reared at long day-lengths. A similar maternal control of diapause in progeny is reported in several insect orders including Diptera (Vinogradova \& Zinovjeva, 1972; Ring, 1967; Saunders, 1987; McWatters \& Saunders, 1997), Hymenoptera (Schneiderman \& Horowitz, 1958; Saunders, 1965; Ivanov \& Reznik, 2008), Lepidoptera (Yamashita, 1996), Hemiptera (Shintani, 2009) and Coleoptera (Kuang et al., 2011). In addition to insects, a similar maternal effect is also reported in Daphnia the females of which transmit information on photoperiod to their offspring, which induces them to produce resting eggs (Alekseev \& Lampert, 2001). Ovarian transplants in S. bullata indicate that the information regulating the maternal effect is transferred to the ovary sometime between the end of larval life and the third day of adult life (Rockey et al, 1989). Thus, the maternal effect is transferred to the eggs before they are fertilized and embryonic development begins. Gamma aminobutyric acid (GABA) and octopamine may be involved in the transfer of information from mother to progeny (Webb \& Denlinger, 1998). There is a transcript unique to the ovary of a female that expresses the maternal effect by means of differential display of mRNA, but the function of the protein that it encodes is unknown (Denlinger, 1998). There are few studies on the molecular mechanism regulating the maternal effect, especially at the protein level, although the genetic basis and ecological adaptations of this effect are well documented (Mousseau \& Fox, 1998; Rasanen \& Kruuk, 2007).

This study reports that the ovaries from mothers reared under long-day and short day conditions either synthesize different protein products or produce different levels of certain proteins. Two-dimensional gel electrophoresis (2-DE) was carried out to separate total proteins from the ovaries of 2 day-old adult flies in the two groups of mothers. Proteins that had significantly different levels of abundance were identified using Capillary-liquid chromatography-nanospray tandem mass spectrometry (Nano-LC/MS/MS). The results indicate an increase in the abundance of 3 actin-binding proteins, Twinstar CG4254-PA, muscle protein 20-like protein and GA13413-PA, in the ovaries of females reared under short-day conditions, which suggests that regulation of the actin cytoskeleton may be associated with this maternal effect in the flesh fly.

\section{MATERIAL AND METHODS}

\section{Fly rearing}

A colony of $S$. bullata was maintained as previously described (Denlinger, 1972). Long-day flies were reared under a

\footnotetext{
* Corresponding author; e-mail: ffhou@public.guangzhou.gd.cn
} 


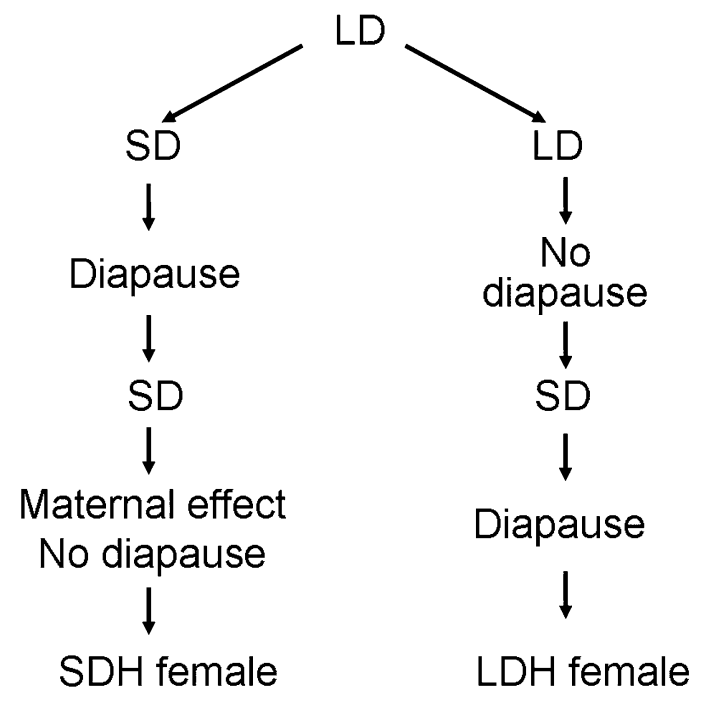

Fig. 1. Rearing conditions experienced by short-day (SDH) and long-day $(\mathrm{LDH})$ females. SD refers to a short day, diapause-inducing environment $\left(12 \mathrm{~L}: 12 \mathrm{D}, 20^{\circ} \mathrm{C}\right)$ during embryonic and larval stages. LD refers to a long day, non diapause-inducing environment $\left(15 \mathrm{~L}: 9 \mathrm{D}, 25^{\circ} \mathrm{C}\right)$.

15L : 9D regime at $25^{\circ} \mathrm{C}$ throughout development and none entered pupal diapause. When long-day flies were transferred at adult eclosion to a $12 \mathrm{~L}: 12 \mathrm{D}$ regime at $25^{\circ} \mathrm{C}$ and their progeny reared under short-day conditions $\left(12 \mathrm{~L}: 12 \mathrm{D}\right.$ and $\left.20^{\circ} \mathrm{C}\right)$, a high percentage entered pupal diapause $(70.6 \%)$ (Herrich \& Denlinger, 1982). Short-day flies originated from flies that had experienced pupal diapause. The flies were maintained under short-day conditions after diapause termination. Under these conditions, the short-day flies expressed the maternal effect with a $0 \%$ diapause recorded in the following generation (Herrich \& Denlinger, 1982). The ovaries of 2 day-old adult progeny of long and short-day female flies reared as shown in Fig. 1 were dissected from isolated abdomens and transferred to an ice-cold microfuge tube for extraction of protein.

\section{Extraction of proteins}

The ovaries were homogenized on ice in a lysis buffer containing $20 \mathrm{mM}$ Tris- $\mathrm{HCl}(\mathrm{pH} 8.0), 1 \mathrm{mM}$ EDTA and a complete protease inhibitor cocktail (Roche, Mannheim, Germany). The homogenates were sonicated using a microtip and centrifuged $\left(16,000 \mathrm{~g}\right.$ for $60 \mathrm{~min}$ at $\left.4^{\circ} \mathrm{C}\right)$. Protein supernatants were purified using the ReadyPrepTM 2D cleanup kit (BioRad) according to the manufacturer's instructions and resolved in general-purpose rehydration buffer containing $8 \mathrm{M}$ urea, 2\% (w/v) CHAPS, $0.2 \%(\mathrm{w} / \mathrm{v})$ Bio-Lyte 3/10 ampholyte, $0.002 \%(\mathrm{w} / \mathrm{v})$ bromophenol blue and $50 \mathrm{mM}$ dithiothreitol (DTT). Concentrations of proteins in the rehydration buffer were determined using an $\mathrm{RC} / \mathrm{DC}^{\mathrm{TM}}$ protein assay (BioRad) prior to two-dimensional polyacrylamide gel electrophoresis (2D-PAGE).

\section{D-PAGE}

Protein separation, detection, analysis and identification were done as described by Li et al. (2008, 2009a, b) with slight modifications. The resulting protein samples $(200 \mu \mathrm{g}$ of protein) underwent isoelectric focusing (IEF) on immobilized $\mathrm{pH}$ gradient (IPG) strips (pH 3-10 non-linear, $11 \mathrm{~cm}$, BioRad) in a PROTEAN IEF Cell (BioRad). The IPG strips were rehydrated for $12 \mathrm{~h}$ at room temperature. The following running conditions were then used: $400 \mathrm{~V}$ for $20 \mathrm{~min}, 8,000 \mathrm{~V}$ for $2.5 \mathrm{~h}$ and 8,000 $\mathrm{V}$ for $35,000 \mathrm{~V}-\mathrm{h}$ with a $\mathrm{pH}$ range of $3-10$ at $20^{\circ} \mathrm{C}$. A current limit of $50 \mu \mathrm{A}$ current was used per strip. After the IEF run, the IPG strips were incubated at room temperature for $20 \mathrm{~min}$ in equilibration buffer [6 $\mathrm{M}$ urea, $1.5 \mathrm{M}$ Tris- $\mathrm{HCl}, \mathrm{pH} 8.8,30 \%$ $(\mathrm{v} / \mathrm{v})$ glycerol, $2 \%(\mathrm{w} / \mathrm{v})$ SDS] containing $2 \%(\mathrm{w} / \mathrm{v})$ DTT, followed by $20 \mathrm{~min}$ incubation in the same equilibration buffer containing $2.5 \%(\mathrm{w} / \mathrm{v})$ iodoacetamide instead of DTT.

Second-dimension electrophoresis was performed on precise SDS polyacrylamide gradient gels $(8-16 \%)$ in a BioRad Criterion Cell. Electrophoresis was carried out at a steady voltage of $200 \mathrm{~V}$ for about $60 \mathrm{~min}$ until the bromophenol blue dye had completely migrated out of the gels. Five independent samples for both long-day and short-day females were separated on 2-DE gels.

\section{Staining of 2D-PAGE and image analysis}

Gels were fixed overnight in a $100 \mathrm{ml}$ aqueous solution containing $40 \%$ ethanol and $10 \%$ acetic acid. The fixed gels were then washed 3 times with $200 \mathrm{ml}$ distilled water for $5 \mathrm{~min}$. The separated proteins were visualized after staining with Bio-safe Coomassie blue. The stained 2-DE gels were scanned using a BioRad VersaDoc imaging system (Model 3000 from BioRad). Images of the scanned 2-DE gels were processed using PDQuest software (version 8.0, BioRad). The analysis included automatic detection, normalization, quantification of protein spots, and matching of control and treatment gels. The relative change in protein abundance for each protein spot was calculated by quantitative comparisons of the averaged normalized spot quantity between two conditions. A two-tailed non-paired Student's $t$-test was performed to determine if the relative change was statistically significant. Protein spots of interest were subject to LCMS/MS.

\section{In-gel trypsin digestion}

Protein spots of interest were automatically excised from the 2-DE gels by a spot cutter (BioRad) and in-gel digested with sequencing grade trypsin from Promega (Madison, WI) according to standard protocols provided by Millipore (Bedford, MA). Gel pieces were twice washed in $50 \%$ methanol $/ 5 \%$ acetic acid for $1 \mathrm{~h}$ and then dehydrated in acetonitrile. The gel bands were rehydrated and incubated with DTT solution $(5 \mathrm{mg} / \mathrm{ml}$ in $100 \mathrm{mM}$ ammonium bicarbonate) for $30 \mathrm{~min}$ prior to the addition of $15 \mathrm{mg} / \mathrm{ml}$ iodoacetamide in $100 \mathrm{mM}$ ammonium bicarbonate solution. Iodoacetamide $(15 \mathrm{mg} / \mathrm{ml}$ iodoacetamide in 100 $\mathrm{mM}$ ammonium bicarbonate solution) was incubated with the gel bands in darkness for $30 \mathrm{~min}$ and removed. The gel bands were washed again in cycles with acetonitrile and ammonium bicarbonate $(100 \mathrm{mM})$, in $5 \mathrm{~min}$ increments. The gels were then dried in a speed vac and rehydrated in $50 \mu \mathrm{l}$ sequencing grade modified trypsin at a concentration of $20 \mu \mathrm{g} / \mathrm{mL}$ in $50 \mathrm{mM}$ ammonium bicarbonate for $10 \mathrm{~min}$. Twenty microliters of 50 $\mathrm{mM}$ ammonium bicarbonate were added to the gel spots and the mixture incubated at room temperature overnight. The peptides were extracted several times from the polyacrylamide gel with $50 \%$ acetonitrile and 5\% formic acid, pooled together and then dried in a speed vacuum to approximately $25 \mu 1$.

\section{Nano-LC-MS/MS}

Nano-LC/MS/MS was performed by coupling an UltiMate ${ }^{\mathrm{TM}}$ Plus system (LC-Packings) to a Micromass Hybrid Quadrupole time-of-flight Q-Tof (tm) II mass spectrometer (Micromass, Wythenshawe, UK), operating in a positive ion mode and equipped with an orthogonal nano-spray source from New Objective (Woburn, MA), as recently described in detail by $\mathrm{Li}$ et al. (2010). The LC system was an UltiMate Plus system from LC-Packings A Dionex (Sunnyvale, CA) equipped with a Famos autosampler and Switchos column switcher. Solvent A was water containing $50 \mathrm{mM}$ acetic acid and solvent B acetoni- 


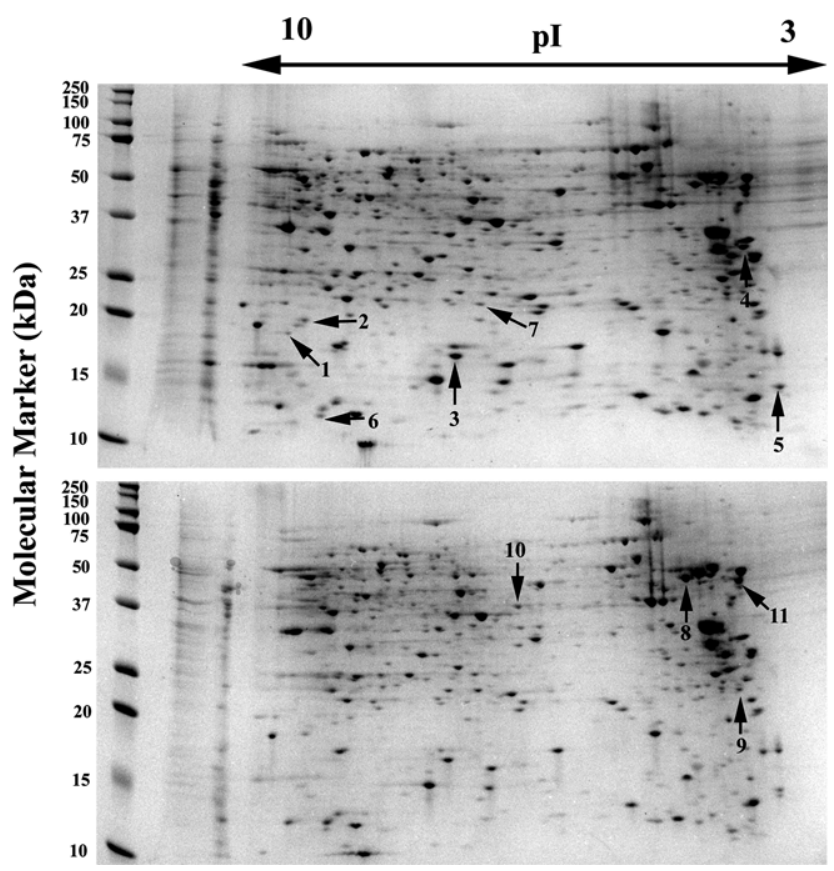

Fig. 2. A 2-dimensional electrophoresis map of the proteins in the ovary of 2-day old females of Sarcophaga bullata exposed to short-day (top panel) and long-day conditions (bottom panel). Numbers refer to proteins that are identified in Table 1. pI $=$ isoelectric point.

trile. Five microliters of each sample was first injected onto the trapping column and then washed with $50 \mathrm{mM}$ acetic acid. The injector port was switched to inject and the peptides were eluted from the trap onto the column. A BioBasic C18 column $(10 \mathrm{~cm}$ $50 \mu \mathrm{M}$ ID, New Objective, Woburn, MA) packed directly in the nano-spray tip was used for chromatographic separations. Peptides were eluted directly off the column into the LTQ system using a gradient of $2-80 \%$ B over $50 \mathrm{~min}$, with a flow rate of $300 \mathrm{nl} / \mathrm{min}$. Total run time was $60 \mathrm{~min}$. The nano-spray source was operated with a spray voltage of $3 \mathrm{KV}$ and a capillary temperature of $200^{\circ} \mathrm{C}$. The scan sequence of the mass spectrometer was based on the TopTen ${ }^{\mathrm{TM}}$ method, a Thermo Scientific preprogrammed method in Excalibur. The analysis was programmed for a full scan recorded between 350 and $2000 \mathrm{Da}$ and a MS/MS scan to generate product ion spectra to determine amino acid sequences in consecutive instrument scans of the 10 most abundant peaks in the spectrum. The collision-induced dissociation fragmentation energy was set to $35 \%$. Dynamic exclusion was enabled by using a repeat count of 2 within $10 \mathrm{~s}$, a mass list size of 200 , an exclusion duration of $350 \mathrm{~s}$, a low mass width of $0.5 \mathrm{Da}$ and high mass width of $1.5 \mathrm{Da}$.

\section{Protein identification}

Sequence information from the MS/MS data was processed by converting the raw data files into a merged file (.mgf file) using MGF creator (merge.pl, a Perl script). The resulting mgf files were searched using the MASCOT MS/MS search engine of Matrix Science version 2.2.1 (Boston, MA, USA) against NCBInr 20080227 (6189142 sequences; 2116873858 residues). Data processing was performed following published standard guidelines (Carr et al., 2004). The mass accuracy of the precursor ions was set to $2.0 \mathrm{Da}$ given that the data were acquired on an ion trap mass analyzer and the fragment mass accuracy was set to $0.5 \mathrm{Da}$. Considered modifications (variable) were methionine oxidation and carbamidomethyl cysteine. Two
Spot No. 2-DE migration patterns Spot volumes

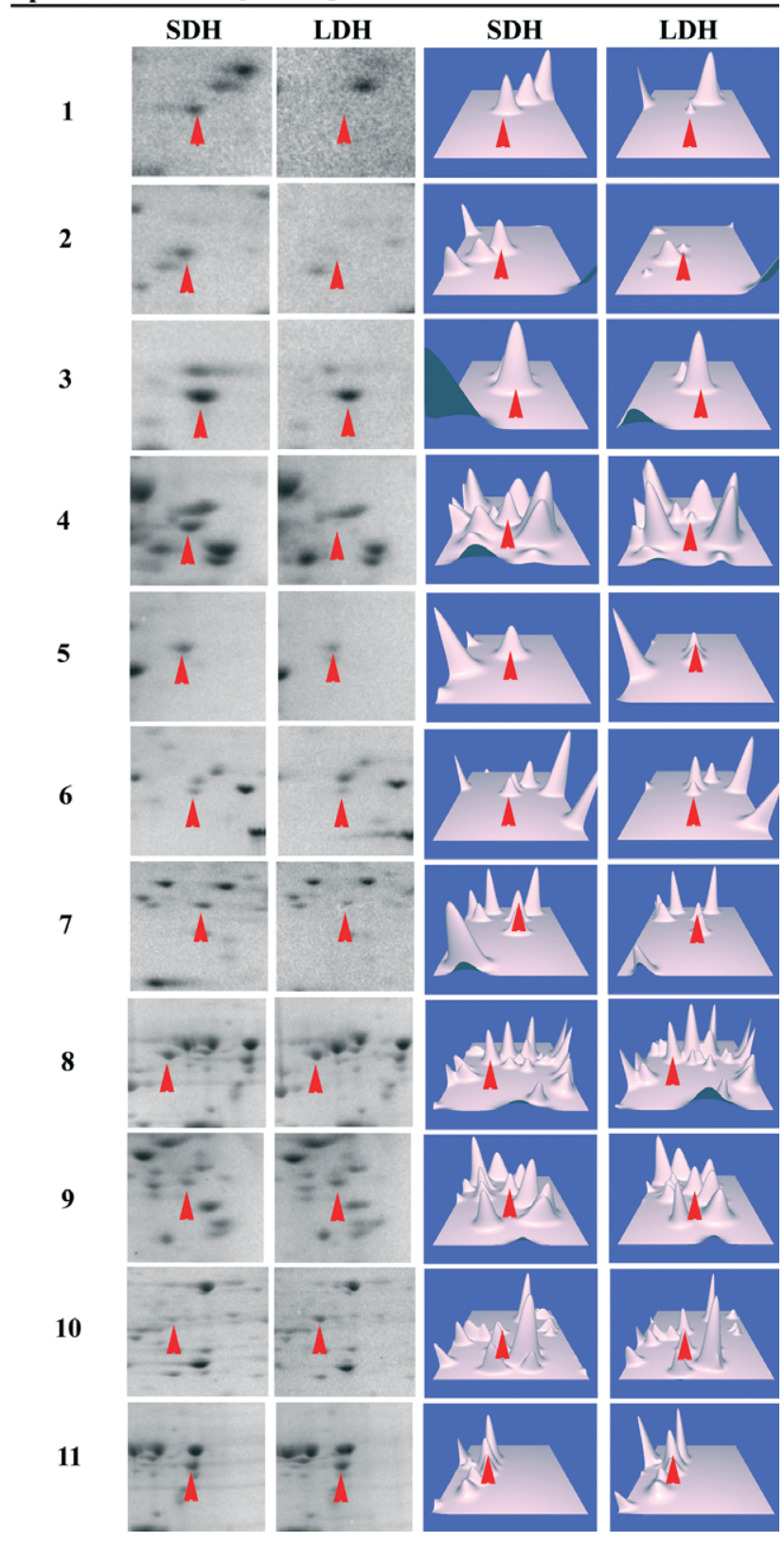

Fig. 3. Selected areas of 2-DE images and corresponding spot volumes of protein spots identified in the ovaries of short-day (SDH) and long-day (LDH) females. Image pairs and detection of protein spots with relative spot volumes were achieved using PDQuest software (version 8.0, BioRad).

missed cleavages for the enzyme were permitted. False discovery rate (FDR) estimation was performed in order to determine a threshold score for a chosen FDR. Peptides with a score $<20$ were filtered. Only proteins with a Mascot score of 50 or higher $(5 \%$ probability that the identification of the protein is incorrect) with a minimum of two unique peptides from one protein having $a-b$ or $-y$ ion sequence tag of five residues or better and with a higher Mascot score than the threshold score were accepted. Identified peptides and proteins were checked manually to confirm the identification. 


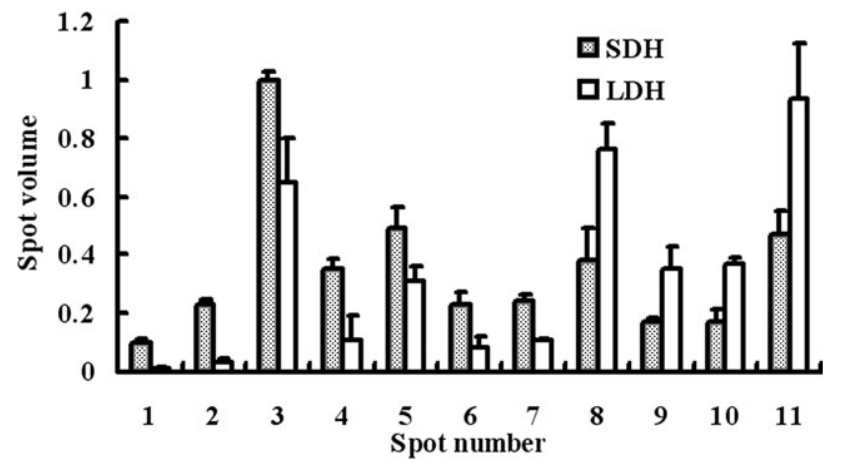

Fig. 4. Relative abundance and standard deviations of the proteins recorded in the ovaries of short-day (SDH) and long-day (LDH) females. All proteins were quantified using PDQuest 8.0.

\section{RESULTS}

\section{Differences in abundance of specific proteins in the ovary}

The 2-DE maps of the ovaries from short-day and long-day females showed good reproducibility and a representative ovary of both groups is shown in Fig. 2. An average of 303 spots (range 299 to 306 spots) and 293 spots (range 290 to 297 spots) were detected in the ovaries of short-day and long-day females, respectively, using 2-DE separation and Coomassie stain. Qualitative and quantitative comparisons were made of the proteins in the ovaries of short-day and long-day females using PDQuest software. Seventy six spots showed a 1.5-fold or greater difference in abundance in the two groups, including 37 with a greater and 39 with a lower abun- dance in short-day females. The abundance of sixty six spots was significantly different $(t$ test $p$ value $<0.05)$ in the two groups, with 30 more and 36 less abundant in short-day females. Eleven relatively abundant proteins that had different levels of abundance but with an average fold change greater than 1.5 -fold and a $t$ test $p$ value $<0.05$ in the two groups were selected for identification and their expression patterns are shown in Fig. 3. The relative abundance of these spots, 7 from short-day and 4 from long-day females, are indicated in Fig. 4.

\section{Protein identification}

The 11 differently abundant proteins were excised and analyzed using Nano-LC/MS/MS, and their corresponding identities and unique peptides identified (Table 1 and 2, respectively). Five proteins that were more abundant in the ovaries of short-day females were similar to the muscle proteins: 20-like protein, GA13413-PA, twinstar CG4254-PA, Gasp CG10287-PA and Ribosomal protein LP1 CG4087-PA. Four proteins that were less abundant in short-day females are similar to the ATP synthase beta subunit fk506-binding protein and storage proteinbinding protein. The 2-D proteome maps include 2 additional unknown proteins that are more abundant and 1 that is less abundant in the ovaries of 2-day old short-day females.

\section{DISCUSSION}

This study compared the proteomic profiles of ovaries of females of $B$. bullata kept under long and short-day conditions and successfully identified 9 proteins that differed in abundance in short-day females. Although these

TABLE 1. Identification (LC/MS/MS) of differentially regulated ovary proteins in Sarcophaga bullata exposed to short-day conditions. Only relatively abundant proteins were selected for mass spectrometric analysis.

\begin{tabular}{|c|c|c|c|c|c|c|c|}
\hline Spot No. & Accession No. & Species & Protein ID & $\begin{array}{c}\text { Sequence } \\
\text { coverage }(\%)\end{array}$ & $\begin{array}{l}\text { Mowse } \\
\text { Score }^{\mathrm{a}}\end{array}$ & $\%$ Change $^{\mathrm{b}}$ & $p$-value \\
\hline \multicolumn{8}{|c|}{ Proteins more abundant in ovaries of 2-day old short-day females } \\
\hline 1 & AAY 68367 & $\begin{array}{l}\text { Anoplophora } \\
\text { glabripennis }\end{array}$ & $\begin{array}{l}\text { muscle protein } \\
\text { 20-like protein }\end{array}$ & 22 & 253 & 586 & 0.001 \\
\hline 2 & XP_001353028 & $\begin{array}{c}\text { Drosophila } \\
\text { pseudoobscura }\end{array}$ & GA13413-PA & 38 & 329 & 700 & 0.000 \\
\hline 3 & NP_477034 & $\begin{array}{l}\text { Drosophila } \\
\text { melanogaster }\end{array}$ & twinstar CG4254-PA & 70 & 559 & 55 & 0.016 \\
\hline 4 & NP_649611 & $\begin{array}{l}\text { Drosophila } \\
\text { melanogaster }\end{array}$ & $\begin{array}{l}\text { Gasp CG10287-PA, } \\
\text { isoform A }\end{array}$ & 34 & 386 & 223 & 0.010 \\
\hline 5 & NP_476630 & $\begin{array}{l}\text { Drosophila } \\
\text { melanogaster }\end{array}$ & $\begin{array}{l}\text { Ribosomal protein } \\
\text { LP1 CG4087-PA }\end{array}$ & 34 & 191 & 59 & 0.022 \\
\hline 6 & - & - & Unknown & 2 & 91 & 199 & 0.021 \\
\hline 7 & - & - & Unknown & 4 & 129 & 120 & 0.001 \\
\hline \multicolumn{8}{|c|}{ Proteins less abundant in the ovaries of 2-day old short-day females } \\
\hline 8 & CAA50332 & $\begin{array}{l}\text { Drosophila } \\
\text { melanogaster }\end{array}$ & $\begin{array}{l}\text { ATP synthase } \\
\text { beta subunit }\end{array}$ & 43 & 1087 & -51 & 0.032 \\
\hline 9 & XP_001648889 & Aedes aegypti & $\begin{array}{l}\text { fk506-binding } \\
\text { protein }\end{array}$ & 17 & 201 & -51 & 0.038 \\
\hline 10 & BAA06161 & $\begin{array}{l}\text { Sarcophaga } \\
\text { peregrina }\end{array}$ & $\begin{array}{l}\text { storage protein- } \\
\text {-binding protein }\end{array}$ & 3 & 119 & -55 & 0.002 \\
\hline 11 & - & - & Unknown & 3 & 89 & -50 & 0.043 \\
\hline
\end{tabular}

\footnotetext{
${ }^{a}$ Mowse score $>50$ indicates identity or extensive homology $(\mathrm{P}<0.05)$; higher scores indicate a greater confidence in the identity.

${ }^{b}$ Percentage change is (SE value - control value)/control value*100; + means an increase in protein abundance after exposure to short-day conditions; - means a decrease in protein abundance after exposure to short-day conditions .
} 
TABLE 2. Peptides in the ovary proteins of flesh flies exposed to short-day conditions identified using LC-MS/MS.

\begin{tabular}{|c|c|c|c|c|c|c|}
\hline $\begin{array}{l}\text { Spot } \\
\text { No. }\end{array}$ & Protein ID & $\begin{array}{c}\text { No. of } \\
\text { peptides }\end{array}$ & $\begin{array}{c}\text { Unique } \\
\text { peptides }\end{array}$ & $\begin{array}{l}\text { False discovery } \\
\text { rate }(\%)\end{array}$ & $\begin{array}{c}\text { Threshold } \\
\text { score }\end{array}$ & Peptide sequence* \\
\hline 1 & $\begin{array}{l}\text { muscle protein } \\
\text { 20-like protein }\end{array}$ & 4 & 3 & 0.00 & 26 & $\begin{array}{l}\text { GATQAGQNIGAGR }(59) \\
\text { AGQTVIGLQAGQNK(92)[2] } \\
\text { KDIAQVTNTLFALGR(103) }\end{array}$ \\
\hline 2 & GA13413-PA & 5 & 5 & 0.00 & 15 & $\begin{array}{l}\text { LANALQPGSIK(22) } \\
\text { AGQNVISLQYGSNK(87) } \\
\text { CMENISAFLECAK(62)_QNLNSVVICLQSLGR(80) } \\
\text { NFGVPTQETFQSVDLWER(83) }\end{array}$ \\
\hline 3 & $\begin{array}{c}\text { twinstar } \\
\text { CG4254-PA }\end{array}$ & 9 & 8 & 0.00 & 14 & $\begin{array}{l}\text { SLVGVQK }(35) \\
\text { YVIFYIRDEK(50) } \\
\text { YIQATDLSEASR(60) } \\
\text { MLYSSSFDALKK(55) } \\
\text { KMLYSSSFDALKK(49)[2] } \\
\text { NAEYDQFLEDIQK }(78) \\
\text { YGLFDFEYMHQCQGTSESSK(49) } \\
\end{array}$ \\
\hline 4 & $\begin{array}{l}\text { Gasp CG10287-PA, } \\
\text { isoform A }\end{array}$ & 8 & 6 & 12.00 & 25 & $\begin{array}{l}\text { SELLAGLNSEGR(51) } \\
\text { EYGCPIGTVFK(33) } \\
\text { YQCSPGLAYDR(37) } \\
\text { KSELLAGLNSEGR(80)[3] } \\
\text { NEEVANGFSCPAAGELANAGSFSR(89) } \\
\text { IGDSDGTGNCEDPEDVPGCEDYYGDLDLK(96) }\end{array}$ \\
\hline 5 & $\begin{array}{l}\text { Ribosomal protein } \\
\text { LP1 CG4087-PA }\end{array}$ & 5 & 2 & 20.00 & 20 & $\begin{array}{l}\text { AANVEVEPYWPGLFAK(74)[3] } \\
\text { AELACVYASLILVDDDVAVTGEK(117)[2] }\end{array}$ \\
\hline 6 & - & 2 & 1 & 0.00 & 15 & IGDNVVSVNSIVEINSIK(91)[2] \\
\hline 7 & - & 1 & 1 & 0.00 & 9 & YEELQITAGR(46) \\
\hline 8 & $\begin{array}{l}\text { ATP synthase } \\
\text { beta subunit }\end{array}$ & 13 & 13 & 0.00 & 53 & $\begin{array}{l}\text { IPVGAETLGR(58) } \\
\text { VVDLLAPYAK(53) } \\
\text { TIAMDGTEGLVR(67) } \\
\text { IINVIGEPIDER(53) } \\
\text { AHGGYSVFAGVGER(74) } \\
\text { FTQAGSEVSALLGR(86) } \\
\text { TVLIMELINNVAK(56) } \\
\text { LVLEVAQHLGENTVR(84) } \\
\text { IMDPNIIGQEHYNVAR(63) } \\
\text { FLSQPFQVAEVFTGHAGK(87) } \\
\text { AIAELGIYPAVDPLDSTSR(93) } \\
\text { VLDTGYPIRIPVGAETLGR(59) } \\
\text { IPSAVGYQPTLATDMGSMQER(79) }\end{array}$ \\
\hline 9 & $\begin{array}{l}\text { fk506-binding } \\
\text { protein }\end{array}$ & 4 & 3 & 23.81 & 21 & $\begin{array}{l}\text { LTIPPELGYGDR(59) } \\
\text { KLTIPPELGYGDR(48) } \\
\text { DQPFTFQLGAGQVIK(62)[2] }\end{array}$ \\
\hline 10 & $\begin{array}{l}\text { storage protein- } \\
\text {-binding protein }\end{array}$ & 4 & 2 & 33.33 & 15 & $\begin{array}{l}\text { DFEAFQQLVVYAR(98)[3] } \\
\text { QMNKLVVQLPGQGLLTDDIGLK(24) }\end{array}$ \\
\hline 11 & - & 1 & 1 & 16.67 & 12 & QVEYYFGDANLNR(92) \\
\hline
\end{tabular}

* Only peptides ranked 1 in the MASCOT report (bold) and with scores greater than the threshold value were considered for protein identification and listed. Number in parenthesis following a sequence indicates the Mascot score for each peptide. Underlined residues are methionine oxidized residues. ${ }^{\S}[$ ] indicates the number of peptide-related precursors that share that sequence.

proteins are referred to as ovary proteins it is unlikely they are unique to the ovary. Five of these proteins were more abundant and the other 4 were less abundant in the ovaries of short-day females.

Of particular note are the increases in the abundance of twinstar, muscle protein 20-like protein and GA13413-PA (spot 1-3). Twinstar, a gene encoding a cofilin/ actin depolymerizing factor homologue, is a component of the cytoskeleton that regulates actin cytoskeletal reorganization (Blair et al., 2006) and retains the conserved domains for actin binding and depolymeriza- tion (Bamburg, 1999). Depolymerizaton of actin is recorded in pupae incubated at $17^{\circ} \mathrm{C}$ for 1 or $24 \mathrm{~h}$ after cold treatment (exposure to $-20^{\circ} \mathrm{C}$ for 12 days) (Kayukawa \& Ishikawa, 2009). Short-day females were reared at a lower temperature $\left(12 \mathrm{~L}: 12 \mathrm{D}\right.$ and $\left.20^{\circ} \mathrm{C}\right)$ than long-day females $\left(15 \mathrm{~L}: 9 \mathrm{D}\right.$ and $\left.25^{\circ} \mathrm{C}\right)$. Thus, the increase in the twinstar-a holologue of actin depolymerization factor in short-day females is consistent with the finding that low temperatures result in the depolymerizaton of actin (Kayukawa \& Ishikawa, 2009). Muscle 20-like protein contains an actin-binding domain that is found in 
cytoskeletal proteins. An increase in the abundance of 20 like protein may suggest an increase in actin binding affinity and alteration in the structure of actin.

GA13413-PA contains a calponin homology actinbinding domain that occurs in cytoskeletal and signal transduction proteins from the National Center Biotechnology Information (http://www.ncbi.nlm.nih.gov). All the 3 proteins harbour an actin-binding domain that might be involved in the regulation of cytoskeleton organization. In contrast, a decrease in abundance of fk506binding protein (spot 10) was observed. Fk506-binding protein, a heat shock protein binding immunophilin, binds the $90 \mathrm{kDa}$ heat shock protein. It was first recorded in association with unliganded steroid receptors in their heat shock protein containing heterooligomer form and later in functionally mature steroid receptor complexes (Sinars et al., 2003). Interestingly, fk506-binding protein is associated with the cytoskeleton, most probably with microtubules (Perrot-Applanat et al., 1995). Given that some Drosophila microtubule-associated protein is required for the structure and function of cytoplasmic microtubules during oogenesis (Moon \& Hazelrigg, 2004) fk506binding protein might be related to oogenesis in the ovaries of non-diapause insects. Differential expressions of cytoskeleton components and cytoskeleton rearrangement, particularly the re-distribution of actin are reported to play a role in insect survival at low temperatures (Kim et al., 2006; Kim \& Denlinger, 2009; Colinet et al., 2007). Together, increases in the abundance of the 3 actinbinding proteins twinstar, muscle protein 20-like protein and GA13413-PA and decrease in the abundance of fk506-binding protein may underscore cytoskeleton alterations in the ovaries of short-day females.

There was also an increase in the abundance of ribosomal protein LP1 (spot 5), a key component during the elongation step of protein synthesis, which plays an important role in translation initiation (Mazumder et al., 2003). An increase in abundance of Ribosomal Protein LP1 may suggest enhanced protein synthesis in the ovaries of diapausing short-day females. Interestingly, by using 2-DE and mass spectrometric analysis to compare the brain proteins that are being actively synthesized during diapause in Sarcophaga crassipalpis, it is recorded that diapause involves the silencing of many genes and synthesis of a small number of diapause-unique proteins (Joplin et al., 1990; Li et al., 2007). Thus, the increase in the abundance of Ribosomal Protein LP1 involved in the diapause-suppressing maternal effect may provide further evidence that diapause represents the differential expression of a set of genes (Denlinger, 2002). In addition, a ribosomal protein is known to be required for oogenesis in Drosophila melanogaster (Qian et al., 1988). Translational inactivation of ribosomal protein mRNAs during oogenesis is reported in vertebrates (Hyman \& Wormington, 1988).Thus, the decrease in the abundance of ribosomal protein LP1 in the ovaries of short-day females may also suggest that suppression of this protein might be related to oogenesis in flesh flies.
Another protein, Gasp (spot 4), is more abundant in the ovaries of short-day females. As the rearing temperature experienced by short-day females $\left(20^{\circ} \mathrm{C}\right)$ was lower than that experienced by long-day females $\left(25^{\circ} \mathrm{C}\right)$, this result is consistent with the proteomic report that a Gasp precursor is up-regulated under constant low temperature conditions in a parasitic wasp (Colinet et al., 2007). Gasp, a peritrophin that interacts with chitin, is known to be expressed in the ovary and embryonic tracheae (Barry et al., 1999).The biological functions of Gasp are still poorly understood although peritrophins may be functionally diverse. It is likely that this chitin-binding protein creates a strong matrix by cross-linking chitin chains, which prevents parasites and viruses entering the ovary (Barry et al., 1999). An increase in abundance of Gasp may be a preparative strategy to protect against more diverse parasite and virus invasions of the trachea and gut of short-day females produced by short-day females. On the other hand, an abundance of Gasp may allow short-day females to produce larvae with a stronger exoskeletal structure by increasing their chitin-binding ability since chitin is an exoskeletal material.

Two of the other proteins identified were less abundant in ovaries of short-day females, i.e., more abundant in ovaries of long-day females, include ATP synthase and storage protein-binding protein (spot 8-9, 11). ATP synthase can synthesize adenosine triphosphate (ATP) from adenosine diphosphate (ADP) to create energy. A decrease in the abundance of the ATP synthase beta subunit may suggest a change in ATP level and $[\mathrm{ATP}] /[\mathrm{ADP}]$ ratios in the ovaries of short-day females. Storage protein-binding protein is related to the nutrient storage function of the fat body (Burmester \& Scheller, 1999). A decrease in this protein may be attributed to the decrease in fat body reserves associated with the diapause-suppressing maternal effect. These 2 proteins are functionally involved in energy metabolism. Progeny of long-day females enter diapause and consequently need to accumulate energy reserves for diapause. Thus, it is not surprising that these 2 metabolism-related proteins are more abundant in the ovaries from long-day females. Although it is not possible to use these results to devise a comprehensive mechanistic scheme for the molecular regulation of the maternal effect, this study offers the first proteomic analysis of the maternal effect and provides an insight into the mechanistic basis of the diapausesuppressing effect, which is currently poorly understood.

ACKNOWLEDGEMENTS. I greatly appreciate the guidance and generous help of D.L. Denlinger (Department of Entomology and Evolution, Ecology, and Organismal Biology, The Ohio State University, USA). This work was supported by The Research Fund for the Doctoral Program (New Young Teacher) of Higher Education of China (Grant No. 20104433120005) and the Natural Science Foundation of Guangdong Province, China (Grant No. 10451051501005757) and Specialized Fund for Talent Introduction in Higher Education Institutions in Guangdong to A.Q. Li (No. 343). 


\section{REFERENCES}

AleKseeV V.R. \& LAMPERT W. 2001: Maternal control of resting-egg production in Daphnia. Nature 414: 899-901.

BAmburg J.R. 1999: Proteins of the ADF/Cofilin family: essential regulators of actin dynamics. Annu. Rev. Cell. Dev. Biol. 15: 185-230.

Barry M.K., Triplett A.A. \& Christensen A.C. 1999: A peritrophin-like protein expressed in the embryonic tracheae of Drosophila melanogaster. Insect Biochem. Mol. Biol. 29: 319-327.

Blair A., Tomlinson A., Pham H., Gunsalus K.C., Goldberg M.L. \& LASKI F.A. 2006: Twinstar, the Drosophila homolog of cofilin/ADF, is required for planar cell polarity patterning. Development 133: 1789-1797.

Burmester T. \& Scheller K. 1999: Ligands and receptors: common theme in insect storage protein transport. Naturwissenschaften 86: 468-474.

Carr S., Aebersold R., Baldwin M., Burlingame A., Clauser K. \& NesvizhsKII A. 2004: The need for guidelines in publication of peptide and protein identification data: Working group on publication guidelines for peptide and protein identification data. Mol. Cell. Proteom. 3: 531-533.

Colinet H., Nguyen T.T.A., Cloutier C., Michaud D. \& Hance T. 2007: Proteomic profiling of a parasitic wasp exposed to constant and fluctuating cold exposure. Insect Biochem. Mol. Biol. 37: 1177-1188.

DENLINGER D.L. 1972: Induction and termination of pupal diapause in Sarcophaga (Diptera: Sarcophagidae). Biol. Bull. Woods Hole 142: 11-24.

Denlinger D.L. 1998: Maternal control of fly diapause. In Mousseau T.A. \& Fox C.W. (eds): Maternal Effects as Adaptations. Oxford Univ. Press, New York, pp. 275-87.

Denlinger D.L. 2002: Regulation of diapause. Annu. Rev. Entomol. 47: 93-122.

Henrich V.C. \& Denlinger D.L. 1982: A maternal effect that eliminates pupal diapause in progeny of the flesh fly, Sarcophaga bullata. J. Insect Physiol. 28: 881-884.

HyMAN L.E. \& WormingTon W.M. 1988: Translational inactivation of ribosomal protein mRNAs during Xenopus oocyte maturation. Genes Dev. 2: 598-605.

Ivanov M.F. \& REZNIK S.Y. 2008: Photoperiodic regulation of the diapause of the progeny in Trichogramma embryophagum Htg. (Hymenoptera, Trichogrammatidae): Dynamics of sensitivity to photoperiod at the immature stages of maternal females. Entomol. Rev. 88: 261-268.

Joplin K.H., Yocum G.D. \& Denlinger D.L. 1990: Diapause specific proteins expressed by the brain during the pupal diapause of the flesh fly, Sarcophaga crassipalpis. J. Insect Physiol. 36: 775-783.

KayUKaWA T. \& IsHIKAWA Y. 2009: Chaperonin contributes to cold hardiness of the onion maggot Delia antique through repression of depolymerization of actin at low termperatures. PLOS ONE 4: e8277.

Kim M. \& Denlinger D.L. 2009: Decreases in expression of beta-tubulin and microtubule abundance in flight muscles during diapause in adults of Culex pipiens. Insect Mol. Biol. 18: 295-302.

Kim M., Robich R.M., Rinehart J.P. \& Denlinger D.L. 2006: Upregulation of two actin genes and redistribution of actin during diapause and cold stress in the northern house mosquito, Culex pipiens. J. Insect Physiol. 52: 1226-1233.

KuAng X.J., Xu J., XIA Q.W., He H.M. \& XuE F.S. 2011: Inheritance of the photoperiodic response controlling imaginal summer diapause in the cabbage beetle, Colaphellus bowringi. J. Insect Physiol. 57: 614-619.
Li A.Q. \& Denlinger D.L. 2008: Rapid cold hardening elicits changes in brain protein proTles of the flesh fly, Sarcophaga crassipalpis. Insect Mol. Biol. 17: 565-572.

Li A.Q., Popova-Butler A., Dean D.H. \& Denlinger D.L. 2007: Proteomics of the flesh fly reveals an abundance of upregulated heat shock proteins during pupal diapause. $J$. Insect Physiol. 53: 385-391.

Li A.Q., Benoit J.B., Lopez-Martinez G., Elnitsky M.A., LeE R.E. \& Denlinger D.L. 2009a: Distinct contractile and cytoskeletal protein patterns in the Antarctic midge are elicited by desiccation and rehydration. Proteomics 9: 2788-2797.

Li A.Q., Michaud M.R. \& Denlinger D.L. 2009b: Rapid elevation of Inos and decreases in abundance of other proteins at pupal diapause termination in the flesh fly Sarcophaga crassipalpis. Biochim. Biophys. Acta 1794: 663-668.

Li A.Q., Choi Y.S., Dziema H., Cao R., Cho H.Y., Jung Y.Y. \& Obreitan K. 2010: Proteomic profiling of the epileptic dentate gyrus. Brain. Pathol. 20: 1077-1089.

Mazumder B., Sampath P., Seshadri V., Maitra R.K., DiCorLETO P.E. \& Fox P.L. 2003: Regulated release of L13a from the $60 \mathrm{~S}$ ribosomal subunit as a mechanism of transcriptspecific translational control. Cell 115: 187-198.

McWatters H.G. \& SAunders D.S. 1997: Inheritance of the photoperiodic response controlling larval diapause in the blow fly, Calliphora vicina. J. Insect Physiol. 43: 709-717.

Moon W. \& Hazelrigg T. 2004: The Drosophila microtubuleassociated protein mini spindles is required for cytoplasmic microtubules in oogenesis. Curr. Biol. 14: 1957-1961.

Mousseau T.A. \& Fox C.W. 1998: The adaptive significance of maternal effects. Trends Ecol. Evol. 13: 403-407.

Perrot-Applanat M., Cibert C., Géraud G., Renoir J.M. \& BAULIEU E.E. 1995: The 59 kDa FK506-binding protein, a 90 $\mathrm{kDa}$ heat shock protein binding immunophilin (FKBP59-HBI), is associated with the nucleus, the cytoskeleton and mitotic apparatus. J. Cell Sci. 108: 2037-2051.

Qian S., Hongo S. \& Jacobs-Lorena M. 1988: Antisense ribosomal protein gene expression specifically disrupts oogenesis in Drosophila melanogaster. Proc. Natl. Acad. Sci. USA 85: 9601-9605.

RASANEN K. \& KRUUK L.E. 2007: Maternal effects and evolution at ecological time-scales. Funct. Ecol. 21: 408-421.

RING R.A. 1967: Maternal induction of diapause in the larva of Lucilia caesar L. (Diptera: Calliphoridae). J. Exp. Biol. 46: 123-126.

Rockey S.J., Miller B.B. \& Denlinger D.L. 1989: A diapause maternal effect in the flesh fly, Sarcophaga bullata: transfer of information from mother to progeny. J. Insect Physiol. 35: 553-558.

SAUNDERS D.S. 1965: Larval diapause of maternal origin: induction of diapause in Nasonia vitripennis (Walk.). J. Exp. Biol. 42: 495-508.

SAUNDERS D.S. 1987: Maternal influence on the incidence and duration of larval diapause in Calliphora vicina. Physiol. Entomol. 12: 331-338.

SchneIderman H.A. \& Horowitz J. 1958: The induction and termination of facultative diapause in the chalcid wasps Mormoniella vitripennis (Walker) and Trineptis klugii (Ratzeburg). J. Exp. Biol. 35: 520-551.

SHINTANI Y. 2009: Artificial selection for responsiveness to photoperiodic change alters the response to stationary photoperiods in maternal induction of egg diapause in the rice leaf bug Trigonotylus caelestialium. J. Insect Physiol. 55: 818-824.

Sinars C.R., Cheung-Flynn J., Rimerman R.A., Scammell J.G., Smith D.F. \& Clardy J. 2003: Structure of the large FK506- 
binding protein FKBP51, an Hsp90-binding protein and a component of steroid receptor complexes. Proc. Natl. Acad. Sci. USA 100: 868-873.

Vinogradova E.B. \& Zinovjeva K.B. 1972: Maternal induction of larval diapause in the blowfly, Calliphora vicina. J. Insect Physiol. 18: 2401-2409.

WebB M.L.Z. \& Denlinger D.L. 1998: GABA and picrotoxin alter expression of a maternal effect that influences pupal dia- pause in the flesh fly, Sarcophaga bullata. Physiol. Entomol. 23: 184-191.

YAMASHITA O. 1996: Diapause hormone of the silkworm, Bombyx mori, structure, gene expression and function. $J$. Insect Physiol. 42: 669-679.

Received May 25, 2011; revised and accepted July 27, 2011 